\title{
An Analytical Approach to Maximizing Stakeholders' Value in Manufacturing Firms
}

\author{
Karibo Benaiah Bagshaw \\ Department of Management \\ Rivers State University \\ Port Harcourt, Nigeria
}

Understanding how to maximize stakeholders' value helps organizations improve the social good of society. This study empirically examined how an analytical approach can enhance stakeholders' value maximization (economic and social values) using a structured questionnaire administered to 48 manufacturing firms in Rivers State, Nigeria. The results have correlation coefficients ( $r$ ) of 0.895 and 0.776 , respectively, with $p<0.05$, indicating a strong and significant positive relationship exist between analytical orientation and stakeholders' economic and social value maximization. Therefore, managers of manufacturing firms should apply analytical methodologies in their stakeholders' value management process to support societal well-being.

Keywords: Analytical Approach, Economic Value, Manufacturing Firms, Social Value, Stakeholders.

\section{INTRODUCTION}

The point of a firm's existence is the economic value created when the price the consumers pay for goods and services is higher than the cost of their production (Agandona, 2011). Beyond seeking economic value (profitability), businesses also need to be responsible in delivering a value proposition. The twin goals of being economically profitable and socially responsible are conflicting objectives that an organization must constantly balance This means that, for the ultimate objective of maximizing profit to be achieved, there must be a coordination of efforts between the organization and a network of parties otherwise known as stakeholders. According to Jesen (2000), these stakeholders are a network of persons within the organization (employees) and outside it (customers, suppliers, host communities, governments, and other interest groups).

The success of an organization should be measured by the extent of its satisfaction of all stakeholders, which implies that the management of the stakeholders' value should be seen as an end and also as a means considering that an organization is a vehicle for value creation (Law, and Gunasekaran, 2012). The contention is that if a manufacturing organization focuses on creating value for shareholders only, its goal may not be fully maximized. Until employees are motivated and rewarded as internal constituent stakeholders, credit lenders and shareholders get dividends as rewards, government is compensated for its role at ensuring peaceful and conducive business environment and the society is rewarded for accommodating the business, the organization will 
never achieve its set objectives (Chan, 2005). In recognizing the moral claims of stakeholders, in addition to the claims of shareholders, introduces other values asides from the purely financial in the spectrum the organization's goals. Managing stakeholders is not only instrumental in creating value for shareholders, it is also normative. Having strongly motivated employees and satisfying the interests of all stakeholders is not only a justified objective, but also a means of maximizing the health of society.

The aim of this paper is to ascertain how the analytical approach in strategic orientation can positively affect the maximization of value for stakeholders of manufacturing firms in Rivers State, Nigeria. To achieve this, the relationship between analytical management and two measures of stakeholders' value, economic and social value, were examined.

\section{LITERATURE}

\section{Value Maximization for Stakeholders}

According to Freeman, Wick and Palmer (2004), stakeholders are those individuals who directly or indirectly impact an organization. According to them, these stakeholders include the employees, community, customers, suppliers, government, political parties and other environmental influences. Earlier, Freeman (1984) stated that stakeholders are those persons or group of persons that have guaranteed possession, rights, and interests in the activities of a firm. As indicated by stakeholder theory, firms that excel are those with committed suppliers, clients, workers as well as management (Jensen, 2000). It is also argued that stakeholder theory has received more attention than an organization's operations' impact on society's well-being, as opposed to just satisfying its shareholders (KyereboahColeman, 2007). Harrison and Wicks (2013) observed that firms that treat its employees with upmost regards and duly motivates them financially as well as in non-financial terms can prevent employees from exercising authority in a manner that may hurt the firm because when employee are poorly treated they resort to behaviour that are detrimental to the firms performance, such as strikes, absenteeism, low productivity and lack of commitment.

Stakeholders' value, unlike that of the shareholders, is more broad-based and emphasizes responsibility over profitability, while seeing the organization primarily as a coalition to serve all involved parties. As posited by Jensen (2000), a firm cannot maximize value if it ignores the interests of its stakeholders. Despite the importance of stakeholder value, little attention has been given to what it actually means to create and maximize value for them. The Business Dictionary (2018) suggests that maximizing value for stakeholders entails establishing and adhering to policies that will: (1) minimize cost and waste while maintaining or improving quality; (2) develop the skills and enhance the satisfaction of employees; and (3) contribute to the development of the host community.

According to Bosse, Phillips and Harrison (2009), while economic returns are important to the core stakeholders of an organization, that is the shareholders; other stakeholders also want other forms of value. For example, the need for attention to be paid to maximization of employees' economic value in eliminates the issue of employees using productive time to engage in personal activities such as 'trading' that will yield extra income to them at the expense of productivity to the organization. For the purpose of this study, focus will be on two aspects of stakeholders' value maximization which incorporate not only the tangible value stakeholders search for, but also the non-tangible value (Bosse, Phillips and Harrison, 2009).

These two aspects are:

1. Economic value: Refers to the value a stakeholder derives from the monetary gain and reward from or cost associated with dealing with the organization.

2. Social value: Refers to the utility derived from the product's ability to enhance social self-concept or the affective state the stakeholder has about the organization.

\section{The Analytical Approach}

This paper posits the need for an analytical approach to maximizing stakeholder value. In this context, "analytical orientation" refers to the ability of the organization to systematically evaluate information to 
facilitate decisions regarding the management of stakeholders' value. An organization that deploys this strategy would find useful management information and control systems embedded in the organization to seek information that is not immediately available (Morgan and Strong, 2003). Analysis, as an element of strategic orientation, is regarded as an organization's capacity to build knowledge and store information which enables the organization to learn, thereby securing a competitive edge over its counterparts (Talke, 2007).

Organizations that do not have a culture of analysis as part of their strategic orientation depend on few individuals in the organization to intuitively make key decisions based on their perceptions of any given situation. Only a comparatively small amount of information can be considered when taking decisions in this way. In contrast, organizations with a high analytical capacity find it easy to make decisions and can more easily integrate multiple processes when accomplishing an objective - in this case, maximization of stakeholders' value. In these organizations, critical issues are not decided by guesswork from individual managers, but by careful consideration and deliberations of key individuals within the managerial team who engage in systematic and participative decision making. It is easier to form teams saddled with the responsibility of analyzing capital expenditure and generating new ideas in the organization. Thus, organizations that implement a high degree of analysis as an element of their strategic orientation allocate huge amounts of organizational resources to gathering data to inform better decision making (Venkatraman, 1989).

Analytically oriented organizations actively explore new opportunities, venturing into new markets and retaining competiveness in existing markets. In addition, analytical organizations scan their environment and gather information relating to their objectives of increasing both shareholders' and stakeholders' value. Such organizations also use critical analyses to identify market opportunities, and research and develop products and services to suit the market, thus creating a niche for themselves, leading to an increase in market share and sales volume, which translates to higher profitability.

The application of analysis involving the use of various models and tools such as SWOT (strength, weakness, opportunity, threat) and PESTEL (political, environmental, social, technology, economic and legal) analysis can assist organizations in determining their internal capabilities and organize them for increased competitiveness, thus attracting new investors and investments. Also, by scanning the environment for information regarding customers' needs, the organization enjoys larger market share, which brings about a higher profit margin (Kaya and Seyrek, 2005). Organizations that continuously analyze the environment for customers' and other stakeholder's needs are prepared for an increased revenue base as they identify opportunities in the marketplace; providing products that will satisfy the customers and yield higher profits (Al-Ansaari, Bederr and Chen, 2015). The needs of customers are changing at a rapid rate (Bagshaw, 2014); hence, organizations, through the use of analytical methodologies, forecast, plan and develop products in accordance with these changing needs, which helps to maximize their value for customers.

Thus, the need for managers of manufacturing firms to understand the expected values of their stakeholders, and to efficiently maximize these values through the application of analytical methodology, becomes essential. This paper, therefore, attempts to measure the impact analytical orientation has on the maximization of both the economic and social values of stakeholders. This section has served as the basis for the formulation of the studys' hypotheses:

\section{Research Hypotheses}

The following research hypotheses, stated in a null form, were tested to determine the existence of any significant relationship between analytical orientation and each measure of stakeholders' value maximization.

$\boldsymbol{H}_{01}$ : There is no significant relationship between analytical strategic orientation and stakeholders' economic value maximization among manufacturing firms in Rivers State, Nigeria. 
$\boldsymbol{H}_{02}:$ There is no significant relationship between analytical strategic orientation and stakeholders' social value maximization among manufacturing firms in Rivers State, Nigeria.

\section{METHOD}

The population of the study is 48 manufacturing firms that are registered with the Manufacturers Association of Nigeria in the Rivers State of Nigeria. Since the population is relatively small, the study adopted the population size as the sample size. A cross-sectional survey research method was adopted with a structured questionnaire on analytical strategic orientation and measures of stakeholders' value as economic and social values. The questionnaire was sent to five members of top management staff in strategic departments and units of each of the manufacturing firms, bringing the number of copies of questionnaire distributed to 240.221 copies of the distributed questionnaire which represent $85.8 \%$ of the total distributed questionnaire were retrieved. However, 17 copies of the retrieved copies were discarded as not useable because they were not properly filled. Therefore, 204 (92. 31\%) of the retrieved questionnaire, which embodies $85.0 \%$ of the total distributed copies of questionnaire were used in presentation and analysis of data. Correlation analysis was performed to determine the level of relationship amongst the study variables.

\section{Data Presentation and Results}

The data presentation is intended to identify the level of relationship between an organization's analytical orientation and each measure of stakeholders' value maximization regarding economic and social values. Statistical significance is established at the $95 \%$ level ( $p$-value $<0.05$ ).

\section{a. ANALYTICAL ORIENTATION AND STAKEHOLDERS' ECONOMIC VALUE MAXIMIZATION}

TABLE 1

\section{RESULTS OF CORRELATION ANALYSIS SHOWING THE DIRECTION AND MAGNITUDE OF RELATIONSHIP BETWEEN ANALYTICAL ORIENTATION AND STAKEHOLDERS' ECONOMIC VALUE MAXIMIZATION AMONG MANUFACTURING FIRMS}

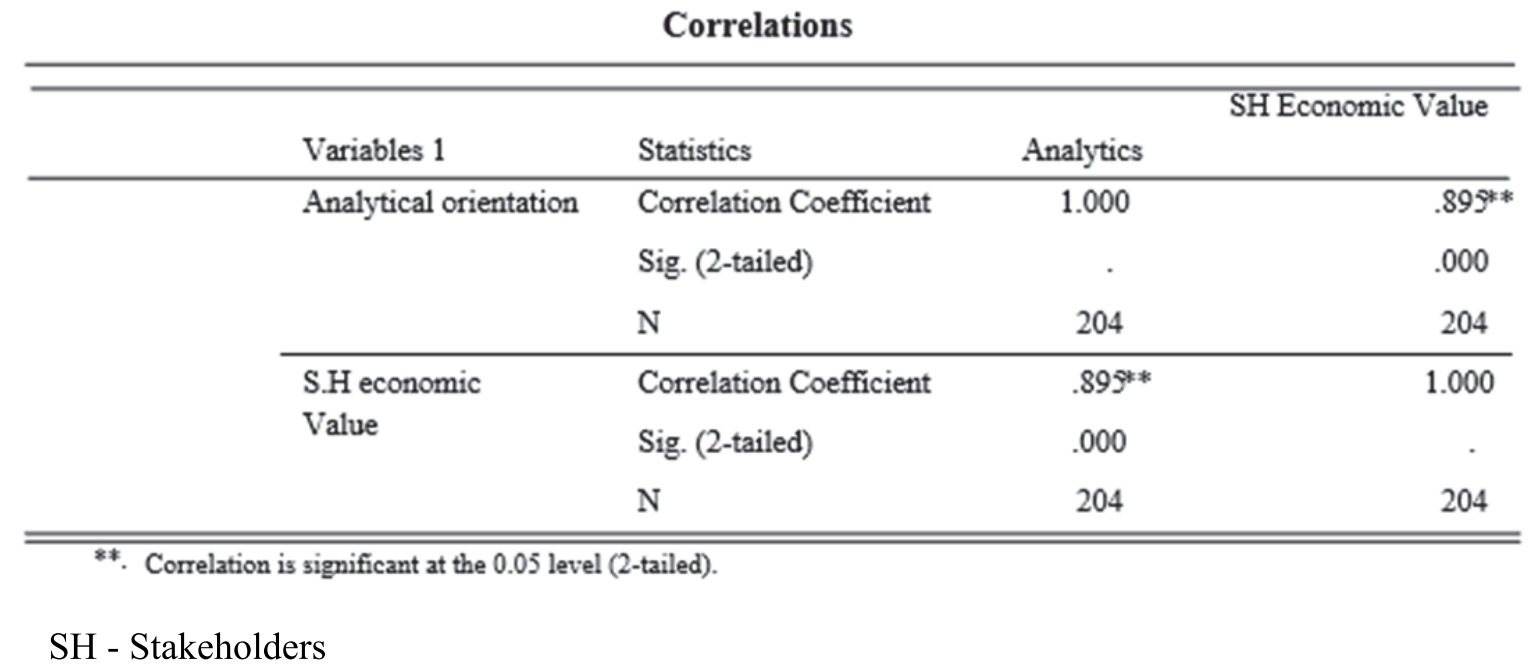

The relationship between analytical orientation and stakeholders' economic value maximization has a correlation co-efficient $(\mathrm{r})=0.895$, indicating that a very strong positive relationship exists between analytical orientation and stakeholders' economic value maximization (Table 1 ). The $p$-value $<0.05$, thus, 
it can be asserted that analytical orientation has a strong influence on stakeholders' economic value maximization. The scatter graph is expressed in Figure 1.

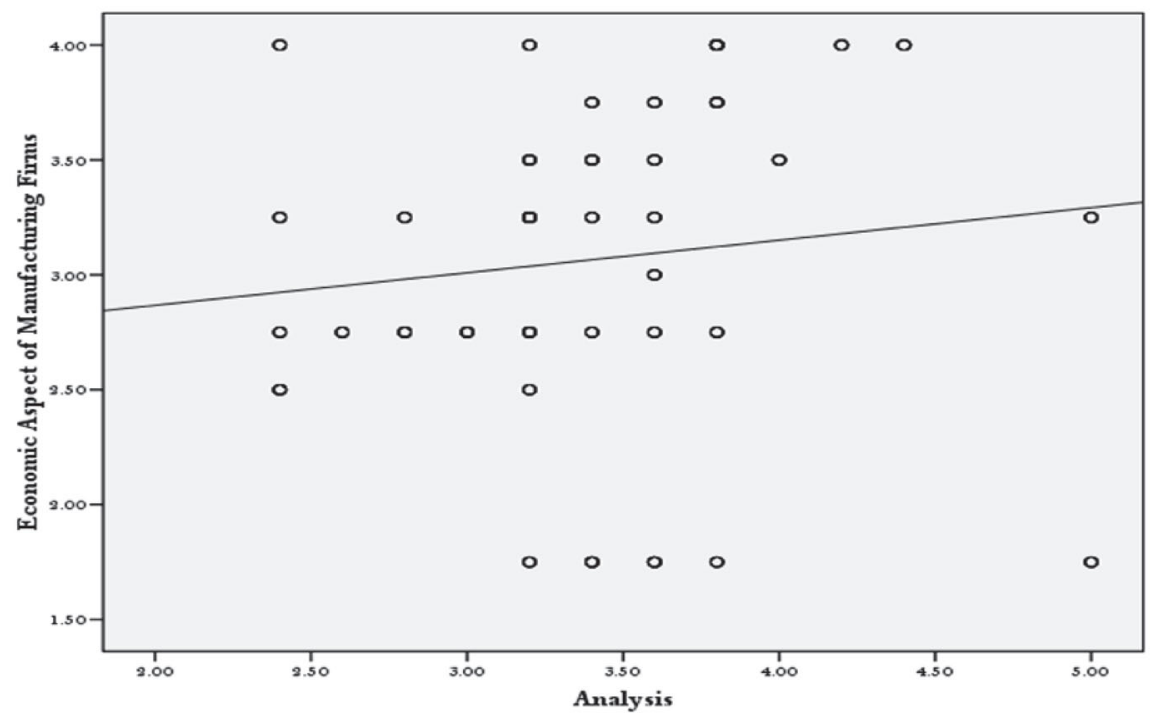

FIGURE 1

THE RELATIONSHIP BETWEEN ANALYTICAL ORIENTATION AND ECONOMIC ASPECT OF STAKEHOLDERS' VALUE MAXIMIZATION OF MANUFACTURING FIRMS

b. ANALYTICS AND STAKEHOLDERS' SOCIAL VALUE MAXIMIZATION

TABLE 2

RESULTS OF CORRELATION ANALYSIS SHOWING THE DIRECTION AND MAGNITUDE OF RELATIONSHIP BETWEEN ANALYTICAL ORIENTATION AND STAKEHOLDERS' SOCIAL VALUE MAXIMIZATION AMONG MANUFACTURING FIRMS

Correlations

\begin{tabular}{|c|c|c|c|}
\hline Variables 1 & Statistics & Analytics & SH Social Value \\
\hline \multirow[t]{3}{*}{ Analytical orientation } & Correlation Coefficient & 1.000 & $.776^{* * *}$ \\
\hline & Sig. (2-tailed) & . & .000 \\
\hline & $\mathrm{N}$ & 204 & 204 \\
\hline \multirow[t]{3}{*}{ SH Social Value } & Correlation Coefficient & $.776^{* * *}$ & 1.000 \\
\hline & Sig. (2-tailed) & .000 & . \\
\hline & $\mathrm{N}$ & 204 & 204 \\
\hline
\end{tabular}

8*. Correlation is significant at the 0.05 level (2-tailed).

SH - Stakeholders

The relationship between analytical orientation and stakeholders' social value maximization is strongly positive $(\mathrm{r}=0.776)$, indicating that a very strong positive relationship exists between analytical 
orientation and stakeholders' social value maximization (Table 2 ). The p-value $<0.05$, thus, it can be asserted that analytical orientation has a strong influence on stakeholders' social value maximization. The scatter graph is expressed in Figure 2.

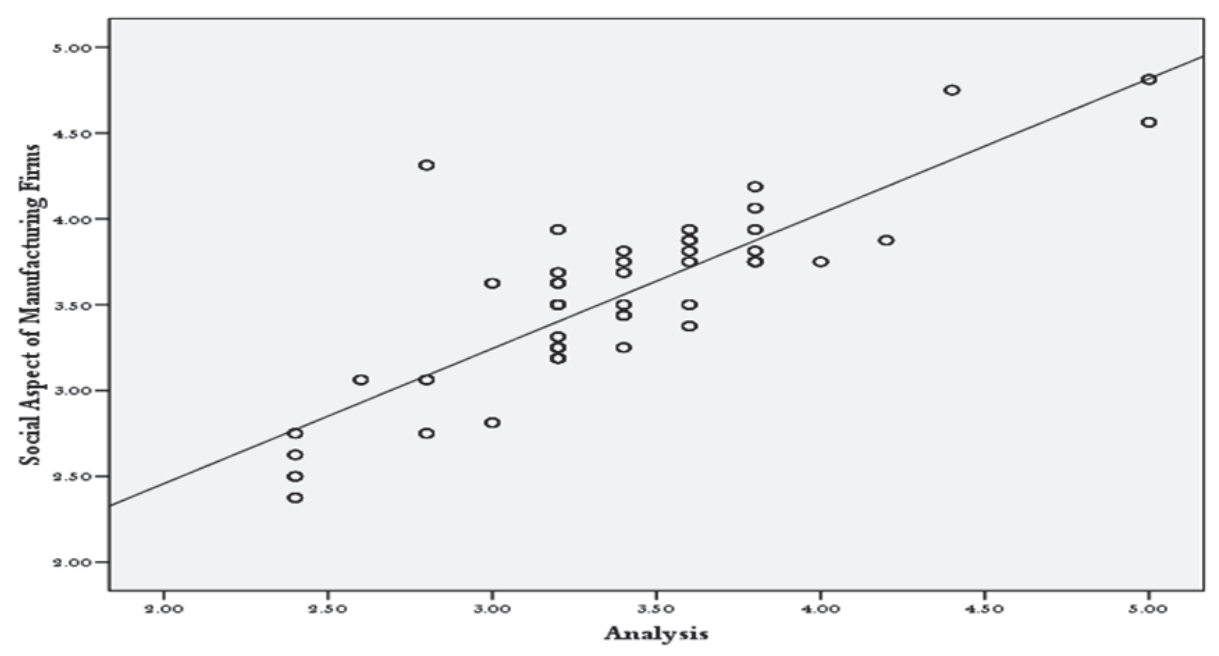

FIGURE 2

SCATTER PLOT SHOWING THE RELATIONSHIP BETWEEN ANALYTICAL ORIENTATION AND SOCIAL VALUE ASPECTS OF MANUFACTURING FIRMS

\section{DISCUSSION}

Lau and Bruton (2011) posit that organizational activities constantly entail reward, control, and management of systems that are internally articulated in order to effectively and efficiently achieve objectives. The analytical actions and systems adopted by a firm are positively associated with the firm's profitability in both stable and volatile environments (Griestein, 2008). An analytical orientation emphasizes effective coordination among an organization's various functional units as well as the use of planning techniques and information system to facilitate better decision making (Venkatraman, 1989).

Weinzimmer, Robin and Michel (2012) observed that analysis assists organizations to assemble information related to environmental changes, identify and initiate innovation processes that affect their success. Importantly, Morgan and Strong (2003) observed that analytical activities positively impact on the organization's business relationship with its stakeholders, regardless of the external environment. An analytical approach is important in the decision-making process for any organization that seeks the best possible solution for its problems (Chan, Huff, Barclay and Copeland, 1998).

In another observation, Vijande, Perez, Gonzalez and Casielles (2005) established that a positive relationship exists between analysis as a strategic orientation dimension and the market domain an organization can achieve, which helps it to appropriately provide for the need of its customers. Through analysis, organizations can forecast market trends, customers' buying behavior and responsiveness to changes in price levels, and subsequently, produce affordable products that meet customers' specifications and needs, helping to maximize customers' value. Through the analytical process, vital information is acquired from customers about product performance; the organization can utilize this information to produce products with new features to enhance its product offering and add value for their customers (Kuckertz and Wagner, 2010). In the same vein, Saura, Contri, Taulet, and Velazquez (2005) observed that an analytical orientation helps in product and process design and planning procedures.

In addition, Vijande et al. (2005) observed that analysis significantly and positively influences the market orientation of an organization. This orientation is described as the degree to which organizations are conscious of and react to the needs of customers. According to Talke (2007), analytically gathering information from stakeholders and appropriately interpreting it is critical to stakeholders' value 
maximization, as well as that of the firm. This indicates that a firm that is analytically oriented is more likely to improve its relationship with its stakeholders. Having an analytic orientation also assists organizations in scanning the political environment at the state, country and international levels, to gather information concerning fiscal and monetary policies and its intervention policies in terms of tariff, levies and taxes; this allows organizations to understand the expectations of the government and subsequently position themselves to be good corporate citizens.

\section{CONCLUSION}

With increased competition in this era of globalization, he role of an analytical approach in maximizing stakeholders' value and building good relationships with society has become imperative for the survival and sustainable growth of manufacturing firms. This paper has established that manufacturing organizations' contribution to societal well-being is a critical issue that requires the systematic evaluation and processing of information and evidence-based decisions regarding the dynamic needs of their stakeholders. While manufacturing firms seek to harmonize the interests of all parties associated with the organization, attention must be paid to how they can maximize the values of their stakeholders, a process which emphasizes responsibility over profitability. The task of maximizing stakeholders' value, therefore, falls on specific individuals within the managerial team who engage in data-driven analysis methods and evidence-based decision making.

Finally, the paper concludes by asserting that an analytical orientation has a significant influence on both economic and measurable social aspects of stakeholders' value maximization. This implies that for organizations to better satisfy their stakeholders, managers should be able to plan and analyze business activities to incorporate the values of the stakeholders while also providing better financial returns. Scanning the environment is one of the analytical processes that helps organizations gather information on stakeholders, including customers, competitors, host community, technology and market. This process provides organizations, particularly in the manufacturing industry, access to tangible information on environmental trends, and helps them identify and adopt innovations that will enhance the value stakeholders place on the organization. Managers of manufacturing firms should, therefore, be aware of environmental changes to help them detect changes in stakeholders' needs, as this will enable the firm to offer superior value to its stakeholders, which will, indirectly, lead to increased societal well-being and sustainable development.

\section{RECOMMENDATIONS}

Based on the data collected and the resulting analysis, this paper recommends that:

1. Managers of manufacturing firms should constantly analyse their stakeholders' value management process to enable them detect trends and patterns in stakeholders' value at every point in time. This will facilitate prediction of future expectations and proactively address issues relating to stakeholders' value maximization.

2. The use of an analytical approach to maximizing stakeholders' value will enable managers and owners of manufacturing firms arrive at evidence-based decisions that will drive favorable business outcomes. 


\section{REFERENCES}

Argandona, A. (2001). Stakeholder theory and value creation. IESE Business School, 2(32), 34-67.

Bagshaw, K.B. (2014). Assessing the application of production scheduling; demand uncertainty and performance of manufacturing firms in Rivers State, Nigeria. Journal of International Review of Management and Business Research, 3(1)38-54

Bosse, D. A., Phillips, R. A., \& Harrison, J. S. (2009). Stakeholders, reciprocity and firm performance. Strategic Management Journal, 30, 447-56.

Business Dictionary (2018). Stakeholder value approach. Retrieved July 15, 2018, from http://www.businessdictionary.com/definition/stakeholder-value-approach.html

Chan, Y. E., Huff, S. L., Barclay, D. W., \& Copeland, D. G. (1998). Business strategic orientation, information systems strategic orientation, and strategic alignment. Information Systems Research, $8(2), 125-150$.

Freeman, R.E, Wicks, A.C., \& Parmer, B.P. (2004). Stakeholder theory and the corporate objective revisited. Organization Science. 15(3), 364- 369.

Freeman, R. (1984). Strategic management: A stakeholder perspective. Boston, MA: Pitman.

Grinstein, A. (2008). The effect of market orientation and its components on innovation consequences: A meta-analysis. Journal of Academy of Marketing Science, 36, 166-73.

Harrison, J.S., \& Wicks, A.C. (2013). Stakeholder theory, value, and firm performance. Business Ethics Quarterly, 23(1), 97-124.

Jensen, M. C. (2000) Value maximization and the corporate objective function. A working paper of Harvard Business School: Negotiations, Organizations, and Markets Unit, 1-19.

Kaya, N., \& Seyrek, I. (2005). Performance impacts of strategic orientations: Evidence from Turkish manufacturing firms. The Journal of American Academy of Business, March, 68- 71.

Kuckertz, A., \& Wagner, M. (2010). The influence of sustainability orientation on entrepreneurial intentions - investigating the role of business experience, Journal of Business Venturing, 25(5), 24-39.

Kyereboah-Coleman, A. (2007). The impact of capital structure on performance of micro finance institutions. The Journal of Risk Finance, 8(1), 56-71.

Lau, C. M., \& Bruton, G. D. (2011). Strategic orientations and strategies of high technology ventures in two transition economies. Journal of World Business, 46(3), 71-380.

Morgan, R. E., \& Strong, C. A. (2003). Business performance and dimensions of strategic orientation. Journal of Business Research, 56(3), 163-176.

Saura, G. I., Contrí, B. G., Taulet, C. A., \& Velázquez, M. B. (2005). Relationships among customer orientation, service orientation and job satisfaction in financial services. International Journal of Service Industry Management, 16(5), 497-525.

Talke, K. (2007). Corporate mindset of innovating firms: Influences on new product performance. Journal of Engineering and Technology Management, 24(1-2), 76-91.

Venkatraman, N. (1989). Strategic orientation of business enterprises: The construct, dimensionality, and measurement. Management science, 35(8), 942-962.

Vijande, M. L. S., Perez, M. J. S., Gonzalez, L. I. A., \& Casielles, R. V. C. (2005). Effects of market orientation on business strategic behavior. Journal of Strategic Marketing, 13, 17-42.

Weinzimmer, L. G., Robin, J., \& Michel, E. J. (2012). The measurement of strategic orientation and its efficacy in predicting financial performance. Journal of Business Strategies, 29(2), 81-98. 